\title{
The Philippine spotted deer and the Visayan warty pig
}

\author{
Roger Cox
}

The author conducted a survey in 1985 that revealed dismal prospects for two endangered Philippine mammals. Habitat destruction and hunting pressure have caused local extinction of the spotted deer and the warty pig in the Visayan Islands, and the remaining populations are not expected to survive very much longer if current practices continue. The country's Bureau of Forest Development wants to establish a sanctuary for the deer and has started a captive breeding project, but the depressed state of the economy and political unrest make their work extremely difficult.

Between 21 July and 16 September 1985 a field survey was carried out under the auspices of the IUCN/SSC's Pigs and Peccaries Specialist Group and the Munich-based Zoologische Gesellschaft fur Arten und Populationsschutz (Zoological Society for the Conservation of Species and Populations) to determine the current distribution and conservation status of two endangered Philippine mammals-the Prince Alfred's rusa or Philippine spotted deer Cervus alfredi and the Visayan warty pig Sus barbatus cebifrons. [The taxonomic status of the wild pigs and the deer of the Philippines has recently been reviewed by Groves (1981) and Grubb and Groves (1983). Their revision of the nomenclature has been followed in this article.]

The survey was initiated as a result of information obtained through correspondence with several US and Philippine scientists, which indicated that rapidly accelerating rates of habitat destruction and hunting pressure on all the Visayan islands were seriously threatening the few surviving populations of both these endemic species. Indeed, in parts of the more densely inhabited regions of the Visayas it appeared that some populations of the pig and the deer had already been extirpated and that others were, in all probability, functionally extinct.

Philippine spotted deer and Visayan warty pig

\section{The Visayan Islands}

The Visayas are the central island group of the Philippines (Figure 1). They are bordered on the south by Mindanao, on the west by Palawan, and on the north by Luzon and Mindoro. The main islands in the group are Panay, Negros, Cebu, Bohol, Leyte and Samar. High relief is typical throughout the larger islands and all have rugged interior uplands rising to $750-1000 \mathrm{~m}$. The coastal plains are seldom as much as $16 \mathrm{~km}$ wide, and drainage is generally by short, violent streams of immature development.

The entire Visayan archipelago was once clothed by dense and complex rain forest, but, as in many other parts of the world, vast areas have been destroyed and either replaced by cultivated fields or simply allowed to regenerate in the form of secondary forests, scrub-jungles or tall tropical grasslands. Much of the destruction of the forests of the Visayas may be attributed to the relentless pressure of landless peasants and indigenous tribal groups moving into these areas to clear temporary agricultural plots known as kaingin. The soil of such plots is rapidly exhausted and new plots have to be cleared every few years. It has been estimated that since the Second World War peasant farmers or kaingineros have been responsible for the denudation of about 50,000 
ha of forest land annually, and that the total area destroyed by kaingineros during the period 1960-1971 constituted 40 per cent of total forest destruction (Maturan, 1976).

Bad practices during legitimate logging operations have been another common cause of forest damage, not only through careless damage to trees to be left in situ, but by erosion from ill-planned extraction routes, particularly on steep hillsides. Those patches of rain forest that remain in the Visayan islands collectively contain a great variety of species, but particular stands are characteristically dominated by one or a very few species. The most common species found today in the forests of the Visayas are members of the family Dipterocarpacea, for example Dipterocarpus grandiflorus, Shorea spp., Pterocarpus indicus and Intsia bijuga.

\section{Philippine spotted deer}

The Philippine spotted deer formerly occurred throughout the larger Visayan islands. It has been suggested that this animal may once have been confined solely to the islands of the eastern Visayas (Lydekker, 1898), but a number of other authors have reported that it also occurred on the islands of Panay, Negros, Guimaras and Cebu (Heude, 1888, 1889; Sanchez, 1900; Sanborn, 1952; also see Grubb and Groves, 1983). The results of this survey indicate that small, extremely localized populations of the spotted deer are now found only in certain parts of the more remote forested regions of the four largest Visayan islands-Panay, Negros, Leyte and Samar.

By far the largest surviving population of these animals in the Visayas is located around Mt Baloy

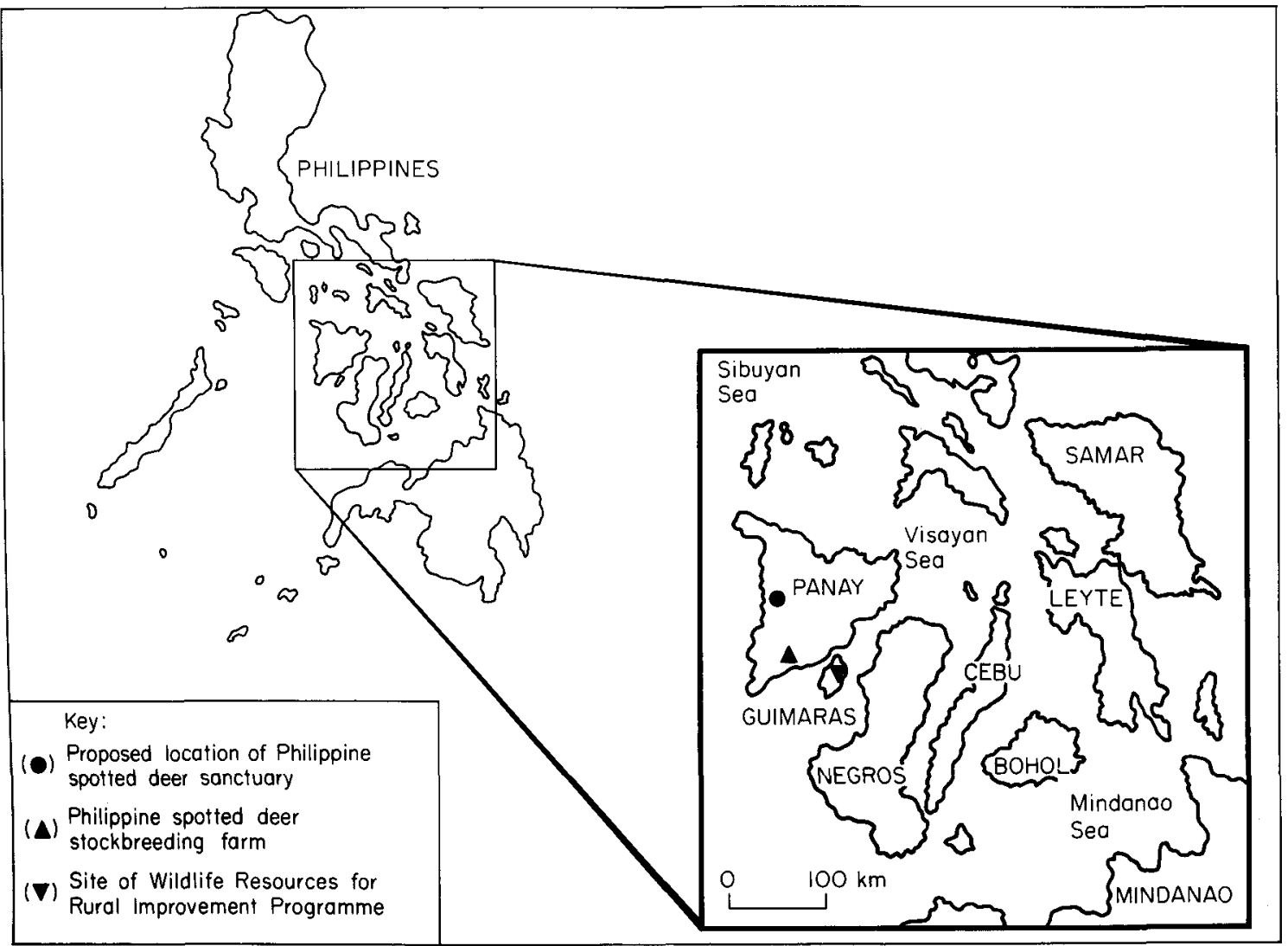

Figure 1. The Visayan islands. 


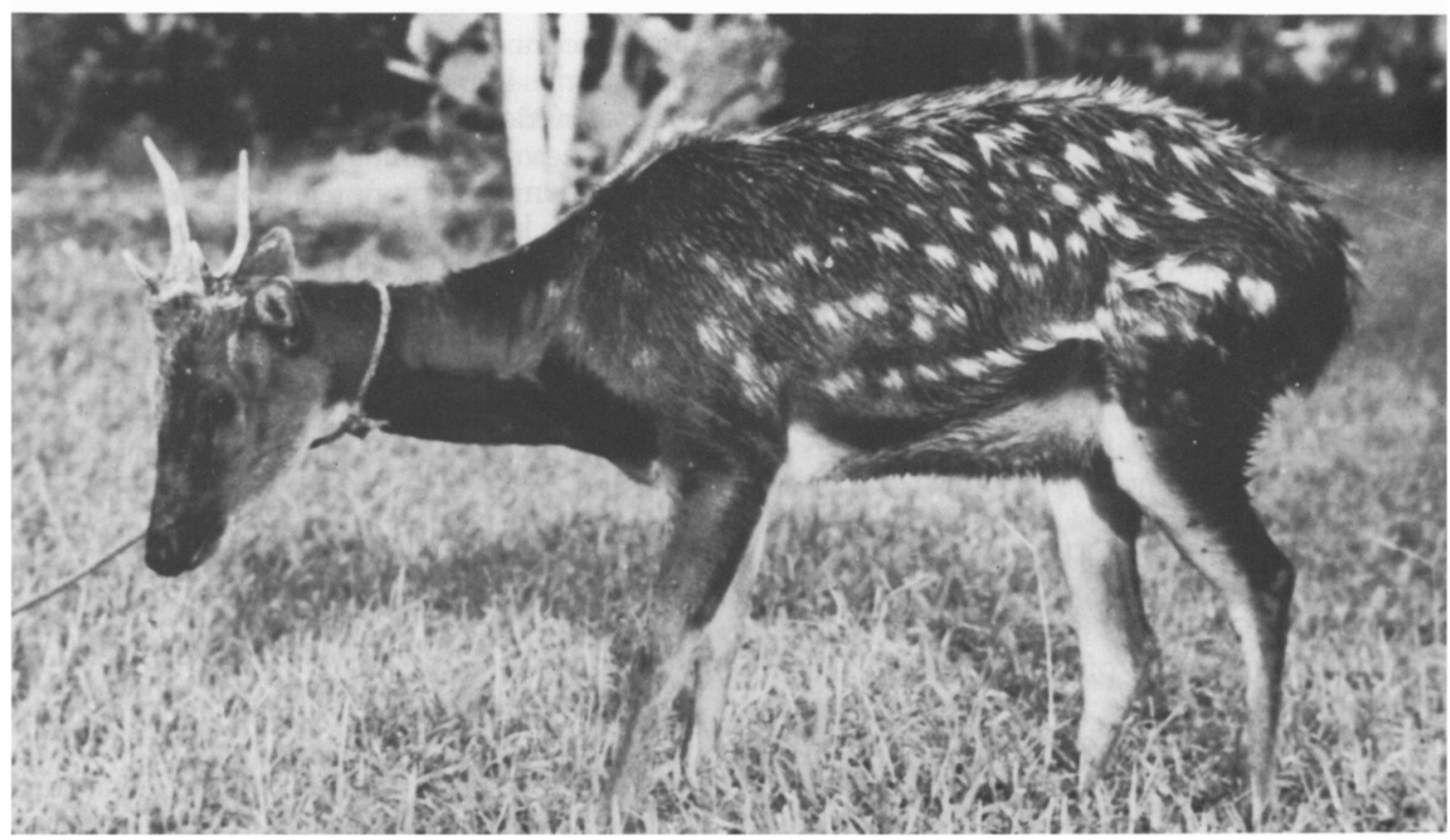

Philippine spotted dear in Mambusao, Panay (Roger Cox).

(1729 $\mathrm{m}$ ) in west Panay, where they inhabit the most extensive expanse of dipterocarp forest on the island (Figure 2). The land is steep and rugged, but the remaining forest, estimated to exceed 40,000 ha (R. Icang, pers. comm.) is nonetheless now threatened by kaingineros. The remoteness of the region makes it practically impossible for forest guards to patrol effectively, and habitat destruction continues virtually unimpeded. Hunting pressure is also severe, especially during the dry season, which on Panay extends from January to the end of June. While it is not possible to estimate the number of surviving deer in the mountains of Panay, several hunters interviewed during the course of this survey reported that they were not able to catch this animal as regularly as they did even five years ago. If, as seems certain, the present rates of hunting and habitat destruction are maintained, it is unlikely that any viable population of this animal will survive for longer than 10-15 years. As a direct result of the findings and recommendations of this survey, the Philippine Bureau of Forest Development (BFD) has expressed interest in establishing a new wildlife sanctuary for the protection of the spotted deer in the Mt Baloy Philippine spotted deer and Visayan warty pig area, but this objective is likely to be hindered in the absence of sufficient funding for further surveys and the preparation of detailed management plans.

In view of the pressures on the west Panay and

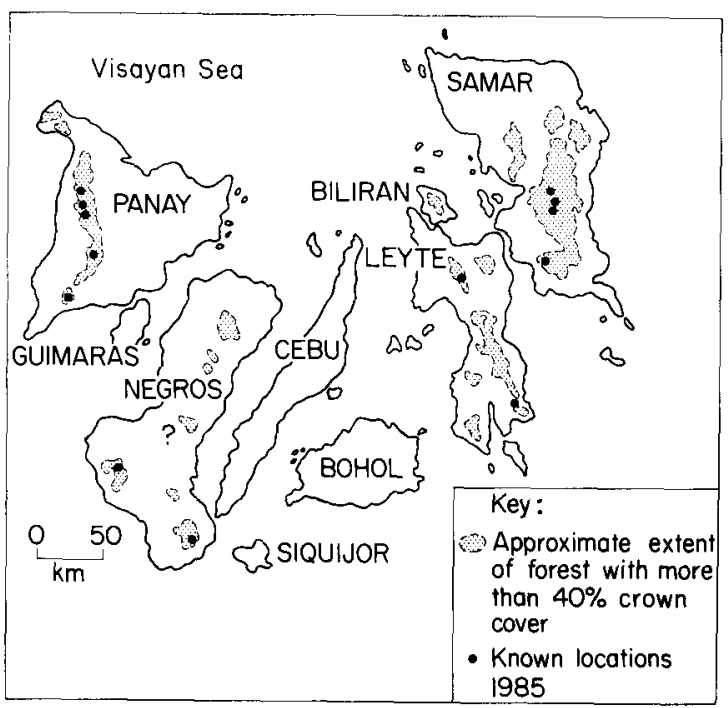

Figure 2. Present distribution of the Philippine spotted deer. 
other small remaining populations, the BFD has also initiated a captive-breeding programme for the spotted deer. This project, which is located near the town of Miagao in southern Panay, was launched as an 'alay' in honour of the former First Lady of the Philippines, Imelda Marcos, on 26 April 1982. The 'Spotted Deer Stockfarming Project' has since been integrated into the locally administered Wildlife Resources for Rural Improvement Programme (WRRIP), of which the stated objectives are to 'create an alternative form of livelihood for the impoverished rural population by developing the potential value of a variety of vulnerable and endangered Philippine birds and mammals'. The Programme is also intended to encourage the development of a proper appreciation of the value of wildlife as an essential component of all ecosystems. To this end, specimens of a number of threatened species, including the Philippine crocodile Crocodylus mindorensis and marine turtles such as the olive ridley Lepidochelys olivacea and leatherback Dermochelys coriacea, are held at a number of locations in Panay. It is eventually hoped to relocate these animals to the island of Guimaras, where a 13-ha Wildlife Management Area is being prepared by the BFD for this purpose. Unfortunately, the WRRIP's Spotted Deer Stockfarming Project site at Miagao was recently raided by members of the New People's Army - a rural guerilla movement-and the five animals that had been held there since 1982 were either slaughtered or lost. The BFD hopes to reestablish a captive herd of these animals in the near future, but the inadequate and intermittent supply of funds for the development of the project, caused largely by the present depressed state of the Philippine economy, has made it increasingly unlikely that the objectives of the WRRIP will be realized, and the Programme has already lost much of its initial impetus.

On the island of Negros, reports of the Philippine spotted deer were obtained only from the Damutan area, in the province of Negros Occidental, and from $\mathrm{Mt}$ Talinis, where the personnel of the BFD's local reforestation project maintain that the species is still found in small numbers in the municipalities of Dauin, Valencia and Sibulan. It is possible that isolated pockets of spotted deer also survive in the now dormant 40 timber concessions that straddle the provincial boundary between Negros Occidental and Negros Oriental, but this is unlikely. Former employees of the timber companies, which once operated in these mountainous areas, report that during the late 1970s they encountered this deer occasionally while logging. In 1979, however, the last timber concessions were cancelled and a large number of people previously employed by the timber companies were left without work. Unable to secure employment elsewhere, many of them reverted to hunting and farming in the forested areas that were once the domain of the timber barons. The influx of kaingineros into the timber concessions on Negros continues to this day, and the problem has been aggravated by the depressed state of the local sugar industry. Negros produced about 75 per cent of the Philippines' total sugar output, and the recent collapse in world prices has forced most sugar farmers to reduce the number of agricultural labourers they employ. Many of these labourers, with no alternative sources of income available to them, have migrated to the interior forest areas to stay alive. The resultant pressure on wildlife populations has been intense and the outlook for most species is extremely bleak. As a valuable source of meat, the spotted deer is a primary target for hunters and has been particularly adversely affected. Informants living in the Philippine American Timber Company concession, the largest single concession on Negros, report that there have been no sightings of spotted deer since 1982 when a single stag was chased down with the help of dogs and butchered. If any deer still inhabit this and other timber concessions on Negros, it is unlikely that they will survive for very much longer.

The Philippine spotted deer is now extinct on the islands of Cebu, Bohol, Siquijor and probably on Masbate (although this island was not visited). The dipterocarp forests in the central Visayas have been devastated by extensive logging and kaingin-making activities. The amount of remaining forest on these islands is smaller than anywhere else in the Philippines, and, on Cebu, fully 90 per cent of the total soil cover now suffers from various degrees of erosion, and nearly 60 per cent of the land is classified as 'severely eroded' (Burley, 1973). There were isolated

Oryx Vol 21 No 1, January 1987 
reports of the spotted rusa from Leyte and Samar in the eastern Visayas, but it is now said to be far less common than the Philippine deer Cervus mariannus, which evidently remains relatively widely distributed throughout the mountainous regions of both islands.

\section{Visayan warty pig}

Little is known about the former range of the Visayan wild pigs, but they were probably once distributed throughout the central Philippine archipelago. Nowadays this animal is still found in the mountain regions of Panay, Negros, Leyte, Samar, Biliran and Bohol, but it is nowhere common and its numbers are certainly declining (Figure 3). The relatively high number of positive responses received from informants on Samar suggests that this island currently supports the largest population of these animals in the central Philippines. Viable pig populations are also found on Leyte, Negros and Panay, but on the smaller islands of Bohol and Biliran their presence is seldom reported and these populations are probably seriously endangered. There are no wild pigs on Siquijor, and only one recent sighting was confirmed on Cebu.

Wild pigs are encountered most frequently when they leave the shelter of the dipterocarp forests adjacent to reforestation projects and kaingins to

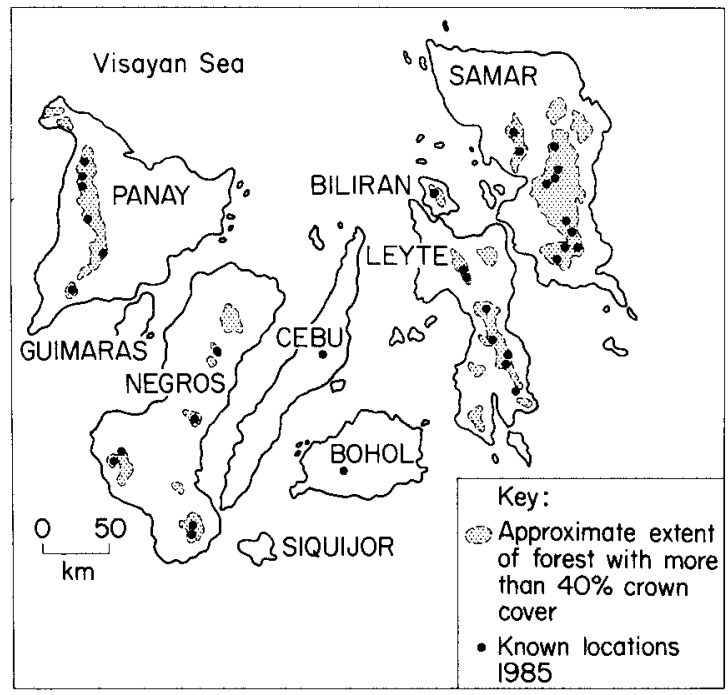

Figure 3. Present distribution of the Visayan warty pig. Philippine spotted deer and Visayan warty pig forage for cultivated vegetables and fallen fruits. In some areas farmers "build fences of bamboo or tree branches and stems and even go to the extent of surrounding whole clearings with sharpened bamboo stakes planted obliquely outward so as to prevent the pigs from coming right inside the field' (Rabor, 1977). Despite these efforts, the damage caused to agricultural smallholdings can be severe. For this reason no special conservation measures have been introduced to protect these animals, which are considered to be pests and, as such, a legitimate target for hunting activities. Some officials from the Department of Wildlife have even suggested that wild pigs should be hunted down and killed wherever possible, although a small minority recognize the deleterious consequences of this recommendation.

A variety of methods are employed to hunt wild pigs, ranging from the conventional use of dogs and snares to crude devices concealed in sweet potatoes which, when compressed by the animal's jaws, explode and cause severe injuries to the head. It is difficult to assess the impact of hunting activities and habitat destruction on wild pig populations in the Visayas, but most informants estimated that if they hunted on a regular basis, they would probably be able to capture one or two wild pigs per month. The importance of these figures becomes clearer when compared with the recollections of one hunter who reported that 15 years ago he would expect to catch at least five pigs on an average 3-4-day hunting trip.

\section{Conclusions}

Although reports of the continued presence of wild pig and spotted deer were obtained from several locations in the Visayan islands, the outlook for both species is poor. A wide variety of inter-related factors, including intense hunting pressure, an increase in the number of people reverting to traditional agricultural methods, widespread political unrest and the depressed state of the Philippine economy, has made it exceedingly difficult for those people and organizations charged with the protection of these animals to carry out their duties effectively. The prognosis for the spotted deer is particularly depressing, and indications are that this animal is 


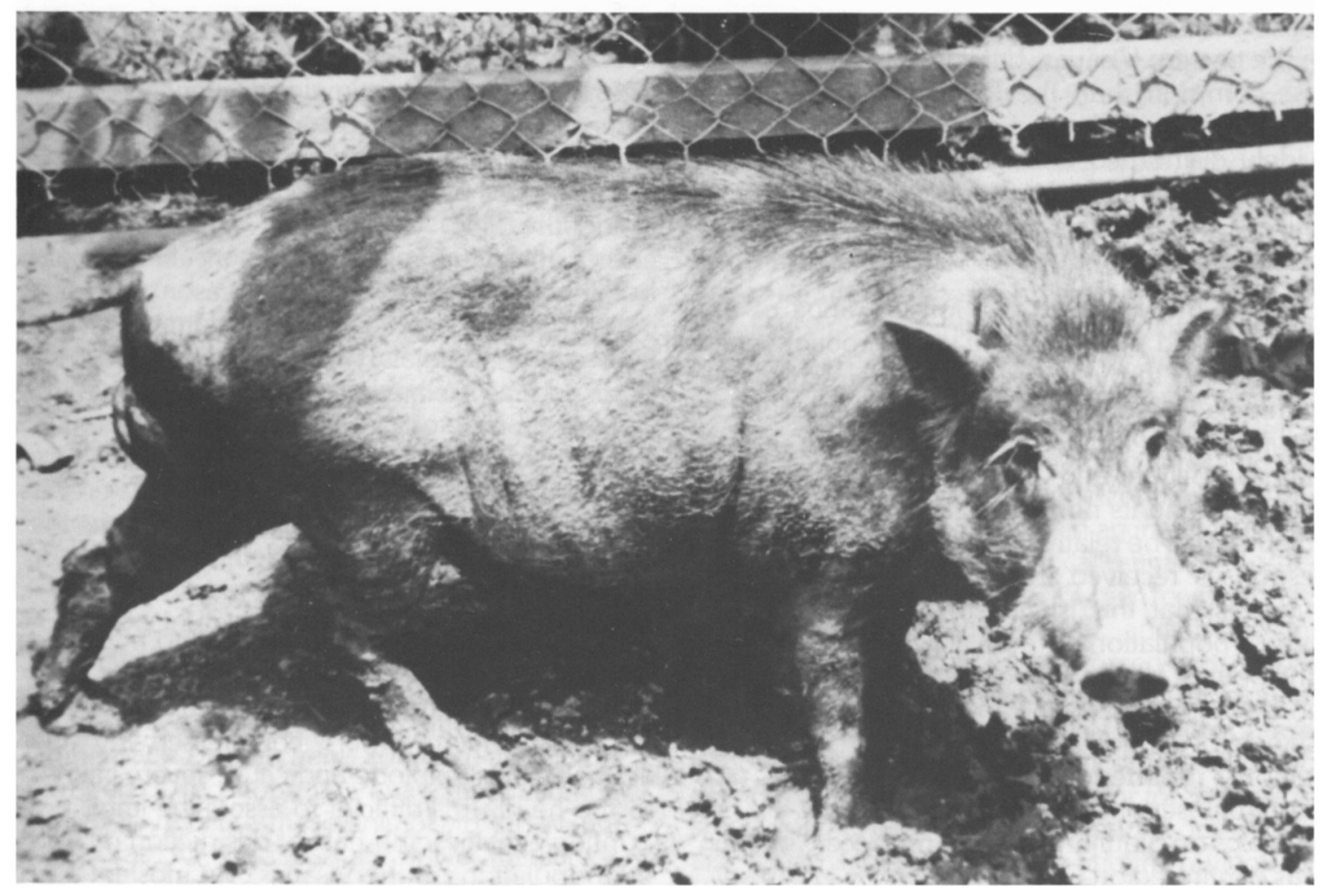

Visayan warty pig in Dao. Panay (Roger Cox).

under intense pressure throughout its restricted, diminishing range. The wild pig has evidently managed to adapt rather more successfully to changing environmental conditions, but existing population levels are certain to decline still further if the present rate of destruction of the remaining forests and natural vegetation cover of the Visayas is maintained.

\section{Acknowledgments}

I am greatly indebted to the staff of the Philippine Bureau of Forest Development, and especially to Jose Lechoncito, Luz Gonzalez, Arturo Bislig and Perla Magsalay who provided much of the information on which this paper is based. The advice and support offered by William Oliver, Ian Grimwood. Roland Wirth, Dioscoro Rabor and Pedro Gonzalez are also gratefully acknowledged.

\section{References}

Burley. T.M. 1973. The Philippines. An Economic and Social Geography. G. Bell, London.

Groves, C.P. 1981. Ancestors for the pigs-taxonomy and 42 history and Anthropology. Res. School of Pacific Studies. Australian Nat. Univ. Press.

Grubb, P. and Groves, C.P. 1983. Notes and taxonomy of the deer (Mammalia, Cervidae) of the Philippines. Zool. Anz. Jena. 210, 119-144.

Heude, P.M. 1888. Etudes sur les ruminants de l'Asie orientale. Cerfs des Philippines et de l'Indo Chine. Memoires concemant ihistorie naturelle de l'empire chinois par des peres de la compagnie de Jesus, 2, 1-64.

Heude, P.M. 1889. Premiere revision de genre Ussa $H$, et rectification de nomenclature. loc cit. 4, 134-141.

Lydekker, R. 1898. The Deer of All Lands. Rowland Ward, London.

Maturan. E.G. 1976. A sociological analysis of the kaingin problem in Negros Oriental. Philipp. Forest Research Joumal. 1, 237-248.

Rabor, D. 1977. Philippine Birds and Mammals. Univ. of the Philippines Press, Quezon City.

Sanborn, C.C. 1952. Philippine Zoological Expedition, 1946-1947. Mammals. Fieldinana Zool. 33, 89-158.

Sanchez, D. 1900. Los mamiferos de Filipinas. An. Soc. esp. Hist. nat. 29(2), 177-290.

Roger Cox, 169 Cranmer Court. Whitehead's Grove, London SW3 $3 \mathrm{HF}$. UK.

Oryx Vol 21 No 1, January 1987 